\title{
Foreign Government Bonds
}

\author{
By Thomas W. Lamont \\ Of J. P. Morgan and Company, New York City
}

$\mathrm{T}^{\mathrm{H}}$ HE field of investment embraced by government bonds has been enormously widened during the last six years, coincidently with the vast increase in national indebtedness. The history of national debts from the Middle Ages up to the time of the outbreak of the World War is an interesting one, and there are many absorbing questions of national policy, finance and economy connected with it. But our subject is more limited: it has to do only with the situation as regards foreign government bonds in this country. It is of interest, however, to note that national debts of the world have increased by $\$ 190,000,000,000$, or about 475 per cent, in the last six years, and, as a natural consequence of this increase, the variety of government bonds and the number of investors in them have been greatly multiplied. These results have made themselves manifest in all the investment markets of the world; but nowhere, perhaps, in greater measure than in the United States.

\section{Foreign Investments of Other Countries}

Great Britain.-The older countries of the world have, for many generations past, been experienced and wise in the investment of their funds in the government obligations of other nations. Great Britain and France, heretofore the foremost creditor nations of the world, have always been the largest investors in such securities. The foreign investments of the British people, at the close of 1913, amounted to roughly $\$ 20,000,000,000$ and were placed all over the world. It is calculated that about $\$ 4,800,000,000$, or 24 per cent of this, had been invested in loans of colonial and foreign governments. Great Britain's present private foreign investments (i.e., not taking into account loans by the British government to other governments) are estimated at about $\$ 16,000$, 000,000 but we have no accurate knowledge of what proportion is now represented by colonial and foreign government bonds. Figures compiled from a recent (London) Stock Exchange Official List give some idea of the number and variety of foreign government bond issues still held by British investors. They show that out of a total of 4,771 securities of all sorts dealt in on the London Exchange, there are 623 bond issues of foreign or colonial governments, states and municipalities.

France.-In France, the story is much the same, except that the French people have placed a larger proportion of their foreign investments in government securities. France, too, has not gone so far afield in making her foreign investments as has Great Britain. Most of her capital loaned abroad has gone to other European countries. The total foreign investments, of all descriptions, of the French people are estimated to have amounted in 1914 to some $\$ 10,000,000,000$, of which 
from $\$ 5,000,000,000$ to $\$ 6,000,000,000$ (or 50 per cent to 60 per cent) were represented by foreign government bonds. The Paris Bourse quotation list at the present time shows listings of 327 foreign government and municipal securities, out of a total of 2,298 issues of all varieties. There are also a number of securities listed exclusively on the departmental Bourses, such as, Lille, Lyons, Marseilles, Bordeaux, Toulons and Nantes, and a number which are not listed on any Bourse but are negotiable in the bank market or "over-the-counter" as we would say in this country.

Other European Countries.-Although the foreign investments of other nations, notably Germany, Holland, Belgium and Switzerland, are not so extensive as those of Great Britain and France, yet those nations, too, have had long experience with foreign investments and foreign government bonds.

\section{Price Movement and Solvency RECORD}

What has been the experience of the old countries with foreign investments? In general, it is a fact that foreign government bonds have formed "the cream" of their investment markets. The bonds of the European countries in particular have enjoyed high rating, and have been considered sound, conservative investtments. The evidence of this is found in the quotations for those securities, covering a period of more than one hundred years to 1914 . In that period, despite armed conflicts now and then, and despite intervals of economic and financial depression, the rate of return on government securities has ruled throughout at the lowest levels; in other words, at the highest grade of credit. The following table shows the yields on British Consols and French Rentes at their highest and lowest prices by ten-year periods, from 1801 to 1914:

\begin{tabular}{|c|c|c|c|c|}
\hline \multirow{2}{*}{ Period } & \multicolumn{2}{|c|}{ British Consols } & \multicolumn{2}{|c|}{ French Rentes } \\
\hline & $\begin{array}{l}\text { Yield at High } \\
\text { Price of Period }\end{array}$ & $\begin{array}{l}\text { Yield at Low } \\
\text { Price of Period }\end{array}$ & $\begin{array}{l}\text { Yield at High } \\
\text { Price of Period }\end{array}$ & $\begin{array}{l}\text { Yield at Low } \\
\text { Price of Period }\end{array}$ \\
\hline $\begin{array}{l}1801-1810 \ldots \ldots \\
1811-1820 \ldots \ldots \\
1821-1830 \ldots \ldots \\
1831-1840 \ldots \ldots \\
1841-1850 \ldots \ldots \\
1851-1860 \ldots \ldots \\
1861-1870 \ldots \ldots \\
1871-1880 \ldots \ldots \\
1881-1890 \ldots \ldots \\
1891-1900 \ldots \ldots \\
1901-1910 \ldots \ldots \\
1911-1914^{*} \ldots \ldots\end{array}$ & $\begin{array}{l}3.80 \% \\
3.56 \\
3.10 \\
3.15 \\
2.95 \\
2.94 \\
3.12 \\
2.98 \\
2.77 \\
2.41 \\
2.66 \\
3.04\end{array}$ & $\begin{array}{l}5.97 \% \\
5.58 \\
4.37 \\
4.01 \\
3.81 \\
3.52 \\
3.54 \\
3.29 \\
3.18 \\
2.95 \\
3.19 \\
3.61\end{array}$ & $\begin{array}{l}4.28 \% \\
5.98 \\
3.48 \\
3.46 \\
3.47 \\
3.49 \\
4.00 \\
3.44 \\
3.11 \\
2.85 \\
2.93 \\
3.08\end{array}$ & $\begin{array}{l}7.60 \% \\
6.67 \\
5.45 \\
6.52 \\
9.23 \\
5.50 \\
5.91 \\
5.96 \\
4.05 \\
3.95 \\
3.20 \\
3.64\end{array}$ \\
\hline
\end{tabular}

* To July 30 .

It is true, of course, that investments in the government bonds of new or backward countries yield higher rates of return. They are less seasoned and investors, therefore, require a higher rate of interest. Investments in such 
countries have not always been fortunate and there have been some losses.

But the solvency record of the governments of the world, when examined as a whole, compares most favorably with that of other classes of borrowers. The council of the Corporation of Foreign Bondholders in London, in each of its annual reports, gives a table showing the government bonds, which, at that time, are in default. An examination of these tables for the thirty years, 1882 to 1911 inclusive, shows that the average amount of government bonds in default annually was about $\$ 126,000,000$. A rough compilation shows that the average total amount of government bonds outstanding for the same period was approximately $\$ 32,500,000,000$. In other words, the average amount of government bonds in default each year per $\$ 100$ of such bonds outstanding was $\$ 0.39$. This compares most favorably with corresponding figures that have been compiled for three important classes of American investment securities, as follows:

Gas and Electric Companies $\$ 0.37$

Railroads ............. 1.84

Industrials . . . . . . . . . $\quad \mathbf{2 . 0 7}$

Characteristics of Government Bonds

Broadly speaking, government bonds may be divided into two classes: First, those which are simply promises to pay or acknowledgments of indebtedness; second, those which are promises to pay and in addition have some special security. The government bonds of the United States and of the chief European countries fall, for the most part, into the first class. In Europe, in many cases, these obligations have no fixed date of maturity, but are in the form of so-called "perpetual" bonds. In these, it is generally stipulated that they may be redeemed on a specific date, at the option of the government, at a specified price, but no date is specified on which they mature. They are, in fact, annuities bearing the privilege of redemption on the part of the government. This form of obligation has never met with great favor among American investors, who are accustomed to bonds maturing with promise to pay on a fixed date.

Government obligations of the other class, that is, those with pledge of special security to assure the payment of principal and interest, have been issued usually under special circumstances. Examples of this class are the Japanese Tobacco $4 \frac{1}{2}$ per cent Sterling Bonds, secured by a charge on the annual net revenue of the Japanese Tobacco Monopoly, the United States of Mexico 5 per cent External Loan of 1899, secured by special hypothecation of 62 per cent of the customs receipts of the country, and the Chinese Government 5 per cent Hukuang Railways Loan of 1911, secured by a first charge upon certain provincial revenues.

\section{Advantages of Government Bonds}

In the last analysis, however, no matter what the special security of a loan may be, its payment, both as to interest and principal, depends on the good faith, and honor, and ability to pay of the promisor government. The objection is sometimes made against government bonds, that they are not subject to foreclosure as is the mortgage bond of a railroad or industrial enterprise, and that there is no means of collecting, against the will of 
the debtor nation, the interest or principal, except by force. This argument loses its force when we consider the disadvantages and onerous burdens to which a nation must submit when it repudiates its obligations, especially its external obligations. It is forced to do without new funds from external sources until it rehabilitates its credit, and the terms of this rehabilitation generally prove to be severe. Moreover, its credit among the other nations of the world is severely injured and it may be decades before it has lived down the evil reputation which inevitably results from repudiation of debts. Not only is the national government's credit impaired, but the credit of the nation's political subdivisions, of its business interests and enterprises of all kinds, large and small, is affected in the money markets of the world. The closely interwoven fabric of international credit and trade in the world today gives moral considerations greater force than legal measures. A nation will hesitate long and fearfully before repudiating its national obligations, especially its external debts payable in other countries. For while, perhaps, there is no such thing as a technical first mortgage upon the resources and the ability of a nation to pay, yet its obligations, payable in foreign countries, have always, in fact, been so considered and have been the first to be taken care of in time of difficulty.

Safety.-The advantages of government bonds, and especially of foreign government bonds, as investments are many, but it will suffice to mention only a few. First, note their safety, which is shown by the course of prices and solvency record previously stated.
The safety of government bonds rests, of course, on the power of governments to tax their people. A government obtains its revenues for debt, service and other purposes by levying taxes which are, in effect, a first charge upon the wealth and income of its people.

Ready Marketability.-Another advantage of government bonds is their ready marketability. In most cases, government loans are made for large amounts and have a wide distribution in many markets. The investor is thereby assured of a broad market for his bonds throughout their life. If the issue is made negotiable in several countries, this marketability is greatly increased and, in addition, protection against an abrupt fall in prices in one market is likely to be afforded by offsetting conditions in other markets. Closely allied to this consideration is the advantage found in the geographical distribution of investment risk. By distributing investments over the international field, the investor may give play to the law of averages and neutralize the effects of violent fluctuation in his investments as a whole. This territorial distribution of risk has long been practiced by European investors to advantage.

High Interest Rate.-At the present time, another advantage to be gained by investment in foreign government bonds is the high interest return which can be obtained. Obligations of the strongest nations of Europe, payable in dollars, may be bought in our market at prices to yield as much as 9 per cent or over. Reference to the table showing the price range of British Consols and French rentes shows that this represents an unprecedented opportunity. 
Aid to Foreign Trade.-One of the most potent arguments to be adduced in favor of investing in foreign loans at this time is the aid which they afford in offsetting the present huge merchandise balance of trade in our favor, and in making possible further purchases of foodstuffs and raw materials by European countries for reconstruction purposes. This phase of the subject will be discussed in a later section of this paper.

\section{America's Investments Abroad}

The experience of American investors with foreign government bonds is of recent origin. Among the more important of such issues, publicly offered in this country during the pre-war period, may be mentioned the loans to Mexico in 1899, 1904, and 1913; to Cuba in 1904, 1909 and 1914; to San Domingo in 1908 and 1913; to Argentina in 1909; to Bolivia in 1909; to China in 1911; and to Japan (three offerings) in 1905. Details as to the conditions which made these loans attractive and advantageous to the American public may be passed over, but we should note a characteristic common to most of them, namely, their international character. Most of the loans mentioned were offered simultaneously in several foreign markets-e.g., London, Paris and Berlin-as well as in New York. The bonds were made payable as to principal and interest, at the option of the holder, in several foreign currencies, as well as in dollars. A world-wide market for them was created. This was an important consideration in the eyes of investors, for assurance was thus given that the holders could always sell in the most favorable market. Financial depressions in this country would not, presumably, similarly affect the markets for such securities in other countries.

According to reliable compilation, there had been issued in this country and was unmatured and unredeemed up to August 1, 1914, a total of roughly $\$ 235,000,000$ of foreign government bonds. It is a matter of conjecture, however, as to how much of this total still remained, at that time, in the hands of our investors. Advantage had been taken of European markets and it is believed that most of these securities had found their way to foreign markets by the time the World War broke out.

In the last five years American investors have purchased foreign government bonds in large volume. In the first place, the necessity for the belligerent nations to conserve all their capital for their own use in carrying on the war led to the closing of their capital markets to countries all over the world, that had been accustomed to borrow from them. Naturally these borrowing countries turned to the United States as the only source of vast accumulated wealth still open to them. Demands of this sort were soon followed by the needs of the belligerent countries for funds with which to pay for their immense purchases of supplies in this country. Their merchandise imports from us were many times their exports to us. And they had, in a comparatively short time, shipped us a huge sum of gold-all they could well afford to spare, and perhaps all that we, from the standpoint of inflation and our own well-being, could well afford to receive. It was the part of wisdom 
for both sides to arrange credits for the settlement of balances growing out of the immense foreign purchases in America. The first transaction of this nature (except for a loan of $\$ 45$,000,000 to Canada in August, 1915) was the issuance of the $\$ 500,000,000$ Anglo-French Five Year 5 per cent External Loan, in October, 1915. The salient features of this loan are well known. The needs of Great Britain and France in this country were covered by the proceeds of this loan until well into the next summer. Then both countries again entered our investment market for funds, this time separately. And from then (August, 1916) on, up to the time that the United States entered the war in April, 1917, bonds of the principal
Allied powers and of other governments were offered to American investors almost continuously. The sum total of these offerings was large. The loans were well taken and absorbed by our investors.

The table below shows, by countries, the amount of foreign government bonds held in this country before the war, the amounts issued and paid off during the war and, finally, the net amount outstanding at the present time. It should be noted that this compilation is restricted to foreign government bonds and does not include any loans which have been made to provinces, municipalities, industrial enterprises or bankers. Neither does it include loans made by the United States government to foreign governments.

Foreign Government Bonds in the United States

(In thousands of dollars)

\begin{tabular}{|c|c|c|c|c|}
\hline & $\begin{array}{c}\text { Amount } \\
\text { Outstanding } \\
\text { July 31, 1914 }\end{array}$ & $\begin{array}{c}\text { Issued August } \\
\text { 1, 1914 to } \\
\text { November } 1,1919\end{array}$ & $\begin{array}{c}\text { Paid off August } \\
\text { 1, 1914 to } \\
\text { November 1, } 1919\end{array}$ & $\begin{array}{c}\text { Amount } \\
\text { Outstanding } \\
\text { November 1, 1919 }\end{array}$ \\
\hline 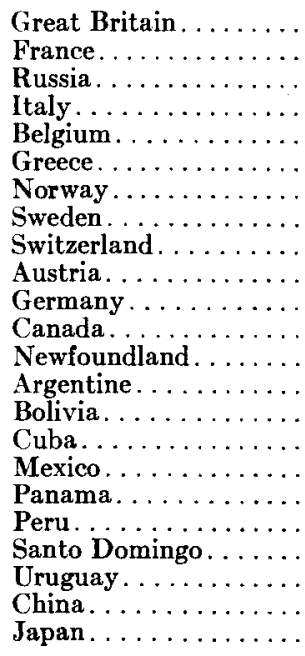 & $\begin{array}{r}9,250 \\
9,200 \\
41,220 \\
16,000 \\
\\
1,000 \\
14,150 \\
\\
7,500 \\
130,478\end{array}$ & $\begin{array}{r}\$ 1,517,818 \\
627,000 \\
85,000 \\
25,000 \\
10,000 \\
\\
8,000 \\
30,000 \\
45,000 \\
\\
20,000 \\
295,000 \\
13,000 \\
152,590 \\
3,400 \\
\\
3,171 \\
4,646 \\
12,750\end{array}$ & $\begin{array}{r}\$ 648,231 \\
353,000 \\
10,000 \\
25,000 \\
25 \\
3,000 \\
5,000 \\
10,000 \\
12,500^{*} \\
18,000^{*} \\
145,000 \\
5,000 \\
93,800 \\
1,279 \\
5,440 \\
\\
260 \\
\\
1,282 \\
4,646 \\
7,000 \\
27,926\end{array}$ & $\begin{array}{r}\$ 869,587 \\
274,000 \\
75,000 \\
\\
10,000 \\
475 \\
5,000 \\
25,000 \\
35,000 \\
\\
2,000 \\
150,000 \\
8,000 \\
68,040 \\
4,321 \\
35,780 \\
16,000 \\
2,911 \\
1,000 \\
12,868 \\
\\
13,950 \\
102,552\end{array}$ \\
\hline Total. . . . . . . . & $\$ 234,798$ & $\$ 2,852,375$ & $\$ 1,376,389$ & $\$ 1,710,784$ \\
\hline
\end{tabular}

* Approximate. 
The total of $\$ 1,710,000,000$, for foreign government bonds outstanding at the present time in the United States, is subject to modification by the amount of such bonds as have been resold in foreign markets. However, these resales probably do not amount to more than $\$ 200,000,000$, at themost, and offsetting them is the considerable amount of internal loans of foreign governments purchased by American investors. In any case, it is apparent that the private investments of the American people in the obligations of foreign governments is still small as compared with the investments of the British and French peoples in similar securities. In this connection, it should be remembered that our government has loaned about $\$ 9,640,000,000$ to foreign governments.

\section{Recent Tendencies}

The extent to which these foreign government issues are listed on the New York Stock Exchange is limited, compared to the listings of similar securities in London and Paris. About forty-six issues make up the total of $\$ 1,718,000,000$ of foreign government bonds outstanding here. Of these, only nineteen, or less than one-half, are listed on the New York Stock Exchange. The listed bonds are, for the most part, those issued during the pre-war period. Many of the loans lately floated here have been of short maturity and for that reason it has not been found advisable or necessary to list them. Of $\$ 2,852,000,000$ of foreign government loans placed in this country in the period from August 1, 1914, to November $1,1919, \$ 1,376,000,000$ were paid off at maturity in the same period.

Another characteristic of the war- time loans, which has already been mentioned, was the direct connection they had with our foreign trade. Almost without exception the loans were made to settle, in part, the export trade balance owing us; in other words, the loans were made for money spent in this country.

A number of the war-time loans took a form which, up to that time, had not been used for government obligations. Such were the collateral loans, secured by deposit, with corporate trustees, of securities of American railroads and other corporations, of obligations of the government of the Dominion of Canada, of the Canadian Provinces and municipalities, and of the governments of other countries, such as, Argentine, Chile, Cuba, Norway, Sweden, Australia, Japan, Egypt, and India. Loans collateralled with such securities were made to Great Britain in November, 1916, and in February, 1917, and to France in 1917. These secured loans matured in one or two years and have been paid off now, except for one lot of British secured notes maturing November 1, 1921.

Several of the foreign government obligations issued during the war have carried a conversion privilege. For example, the United Kingdom of Great Britain and Ireland One- and TwoYear $5 \frac{1}{2}$ per cent Secured Notes, issued in February, 1917, to the amount of $\$ 250,000,000$, were convertible, at the option of the holder, at any time before maturity, into twenty-year $5 \frac{1}{2}$ per cent bonds, payable February 1, 1937, and not subject to prior redemption. This opportunity to obtain twenty-year obligations of Great Britain yielding a high rate of interest-as compared with the yield formerly obtainable on 
obligations of the British government - was availed of by many investors and about $\$ 142,000,000$ of the notes were converted. The Anglo-French Bonds, maturing in October, 1920, likewise carry a conversion privilege. They are convertible into fifteen to twenty-five-year joint and several obligations of Great Britain and France, bearing interest at $4 \frac{1}{2}$ per cent per annum. The $\$ 100,000,000$ French Two-Year $5 \frac{1}{2}$ per cent Secured Notes issued in April, 1917, were also convertible into long term bonds. The holders of these notes, however, had, in addition, an option to take payment in francs instead of dollars, and they elected to take the profit on exchange when the notes fell due, in April, 1919, rather than to convert them.

The foreign government loans which have been issued in this country since the Armistice was signed already show a tendency away from the special features characteristic of the war-time issues. In the first place, the tendency is toward more permanent financing, nearly all of the loans maturing in ten years or later. There is evident a desire to avoid the disadvantages of shortterm financing, and to set the maturity of the loans far enough into the future to carry the borrowing governments over the reconstruction period.

At the present time, the extremely low level of foreign exchange rates offers possibilities for profit not ordinarily obtainable from investments in foreign government bonds. For example, the issue of British three-year notes and ten-year bonds recently (November 1,1919) sold in this country are convertible, at the option of the holder, at 100 and interest, into $\mathrm{Na}$ tional War 5 per cent Bonds, Fourth
Series, at 100 and interest, sterling exchange being computed, for the purpose of conversion, at the fixed rate of $\$ 4.30$ to the pound. The National War Bonds are payable in sterling, at maturity in 1929, at 105 per cent. Assuming that the purchaser of a $\$ 100$ three-year note at the issue price of $\$ 96$ or of a $\$ 100$ ten-year bond at $\$ 96.25$ converted his note or his bond, he would receive $£ 23: 55: 2^{2} / 5 \mathrm{~d}$. principal amount of National War Bonds. As sterling exchange improves, his profits from conversion will increase. If he sold the War Bonds in the London market at 100 he would realize $\$ 113.19$; if he held them until paid at maturity at 105 , he would realize $\$ 118.85$, assuming, in both instances, that sterling exchange were at parity $-\$ 4.8665$ to the pound. In a word, he has a tenyear call on sterling exchange at $\$ 4.30$ to the pound and in the meantime receives a handsome rate of return on a sound investment payable in dollars.

The possibilities of profit combined with safe investment obtained by purchase of such securities are available to all buyers of bonds, and especially to American importers. The importer can, at one and the same time, invest in a prime security yielding a high return on the money invested, and can also obtain a call upon exchange with which to make payment for future importations. When sterling exchange improves, as in the long run it is bound to do, the importer who has invested in such securities will be able to buy goods in the foreign market much cheaper than competitors who have not made such investments. Of course, the purchase by American investors, at the present time, of the internal loans of the European nations, is also attractive 
on account of the prevailing low level of exchange rates. On the other hand, no promise of payment of principal and interest in dollars is obtained.

\section{The Problem of Our Foreign Trade}

America's Export Balance.-America has enjoyed a prodigious foreign trade - her exports for the five years ended June 30,1919 , amounted to no less than $\$ 25,500,000,000$. Her imports were less than half of that sum. Consequently, she piled up a merchandise export balance slightly less than $\$ 14,-$ $000,000,000$. In part settlement of that balance, America received, of course, large shipments of gold. American investors also repurchased a great amount of securities formerly held by European investors. But by far the largest part of that huge export balance was settled by the extension of credit. Calculations have been made indicating that $\$ 11,700,000,000$ was settled in that way, including up to June 30 last, $\$ 9,100,000,000$ credits granted by the United States government to foreign governments. Before America's entrance into the War, American investors had, as we have seen, purchased large loans of foreign governments issued in this country to pay for their purchases of goods in American markets.

Government control of private business has now largely ceased and government loans to finance foreign trade have practically come to an end. And yet the excess of merchandise exports from the United States over imports in the first ten months of 1919 amounts to $\$ 3,388,000,000$-almost a billion dollars more than in the same period in 1918. America cannot go on indefinitely piling up such an export balance. Exports will gradually contract and imports will gradually expand. But even with a gradual working toward equilibrium, the export balance will be very great for some time to come. The world, and especially Europe, urgently needs food, clothing and a long list of other things. America can supply them. And it is important that America should supply them, unless her manufacturers and her merchants and her working people are prepared for an abrupt cutting off of exports and widespread dislocation of business.

If America wants to help in the reconstruction of Europe, if America wants to continue her profitable export trade, she will have to sell her goods on credit-not all, but a good part. American investors - every American who saves-will have opportunities to invest a portion of their savings abroad. They will have opportunities to buy foreign government bonds, to lend to foreign business enterprises and to purchase equities in foreign industries.

America may well follow in the footsteps of the older countries in the field of foreign investment. Along that path, America will discharge her duties and her capacity for universal service, not without profit to herself. 